\title{
Improvement of Biodegradable Biocide's Activity of Peroxyacetic Acid Basis Using Surfactants: Characterization and Stability
}

\author{
Esther Asensio, ${ }^{1}$ Fernando Sanagustín, ${ }^{2}$ Cristina Nerín, ${ }^{1}$ and Milton Rosero-Moreano ${ }^{3}$ \\ ${ }^{1}$ Departamento de Química Analítica, Instituto de Investigación en Ingeniería de Aragón (I3A), Universidad de Zaragoza, \\ 50018 Zaragoza, Spain \\ ${ }^{2}$ Biocidas Biodegradables ZIX, S.L., 22004 Huesca, Spain \\ ${ }^{3}$ Departamento de Química, Universidad de Caldas, Apartado Aéreo 275, Manizales, Colombia
}

Correspondence should be addressed to Esther Asensio; estherac@unizar.es

Received 8 February 2015; Revised 7 July 2015; Accepted 13 July 2015

Academic Editor: Athanasios Katsoyiannis

Copyright (C) 2015 Esther Asensio et al. This is an open access article distributed under the Creative Commons Attribution License, which permits unrestricted use, distribution, and reproduction in any medium, provided the original work is properly cited.

\begin{abstract}
This paper deals with the study of the kinetics decomposition reaction of the peroxyacetic acid under influence of surfactant additives. The peroxyacetic acid shows a decomposition rate of $1.70 \times 10^{-3} \mathrm{~h}^{-1}$ and its activation energy is $66 \mathrm{~kJ} \mathrm{~mol}^{-1}$. The influence of temperature on the reaction of spontaneous decomposition of peroxyacetic acid was studied at two seasonal periods. Peroxyacetic acid standard and four prototypes of biocide samples with known concentration of peroxyacetic acid and hydrogen peroxide were studied. Finally, a factorial analysis ANOVA was carried out to establish significant differences $(p<0.003)$ between the four biocide samples over time with respect to peroxyacetic acid and hydrogen peroxide concentration. From the study carried out, it can be concluded that the biocide with surfactant substances in its composition offers the best stability and its difference versus the other biocides may guarantee a better behaviour.
\end{abstract}

\section{Introduction}

The use of peroxyacetic acid (PAA) as sanitizer in agricultural $[1,2]$ and medical environments $[3,4]$, water and wastewater industry [5], food processing, beverage, and medical and pharmaceutical industries [5] has increased due to its efficient biocide effect: bactericidal [6], virucidal [7], and fungicidal and sporicidal [8] effectiveness, wide range of $\mathrm{pH}$ application [9-11], and absence of halogenated persistent by-products [12]. However, its uncontrollable decomposition rate to acetic acid and oxygen [13] is a question of concern $[9,14]$, as the peroxides, in general, are high-energy-state compounds and, as such, they can be considered thermodynamically unstable [15]. The common commercial sanitizer biocide samples based on PAA contain acetic acid $(10 \% \mathrm{v} / \mathrm{v})$, hydrogen peroxide (HP) $(25 \% \mathrm{v} / \mathrm{v})$, and peroxyacetic acid $(5 \% \mathrm{v} / \mathrm{v})$, with specific gravity being 1.10 [16]. One key parameter of these biocides is the stability versus time. It is believed that the use of surfactants greatly improves the biocide properties of the compounds [13], because cleaning and disinfection of a hard surface comprise the step of treating the surface with a cleaning compound [17-19]. To assess the decomposition rate of their main components such as peroxyacetic acid and hydrogen peroxide, several methods have been developed and among them, double step titration [20], spectrophotometric methods [21-23], enzymatic methods [24], gas chromatography [25], liquid chromatography [26], simultaneous spectra-kinetic determination [27], and flow injection analysis (FIA) method [28] can be mentioned. The chosen method for this assessment study based on liquid chromatography has the advantage of the simultaneous determination of PAA and HP with only one previous derivatization reaction. The quantitative reaction of PAA with methyl $p$-tolyl sulphide (MTS) and the HP with triphenylphosphine (TPP) yields the corresponding methyl $p$-tolyl sulfoxide (MTSO) and triphenylphosphine oxide (TPPO), according to Pinkernell et al. [26].

The aim of this work is to study the decomposition kinetics of PAA and HP in four sanitizer biocide prototypes 
TABLE 1: Analytical characteristics of the validated method.

\begin{tabular}{|c|c|c|c|c|c|c|c|}
\hline Compound & $\begin{array}{c}\mathrm{RT} \\
(\mathrm{min}) \\
\end{array}$ & $\begin{array}{l}\text { Linear range } \\
\left(\mathrm{mmol} \cdot \mathrm{L}^{-1}\right)\end{array}$ & $\begin{array}{l}\text { Limit of detection } \\
\left(\mathrm{mmol} \cdot \mathrm{L}^{-1}\right)\end{array}$ & $\begin{array}{l}\text { Limit of quantification } \\
\left(\mathrm{mmol} \cdot \mathrm{L}^{-1}\right)\end{array}$ & $R^{2}$ & $\begin{array}{c}\text { Recovery } \\
(\%)\end{array}$ & $\begin{array}{l}\text { RSD } \\
(\%) \\
\end{array}$ \\
\hline PAA & 1.39 & $0.023-0.800$ & 0.002 & 0.005 & 0.9996 & 99.5 & 1.3 \\
\hline HP & 3.79 & $0.008-0.270$ & 0.001 & 0.002 & 0.9983 & 96.5 & 1.4 \\
\hline
\end{tabular}

under environmental conditions reflecting realistic situations. These experiments were made in the laboratory and included combinations of stability time (0-63 days), environmental temperature $\left(25-30^{\circ} \mathrm{C}\right)$, and surfactant content added (0-5\%). In addition, PAA and HP concentrations were measured throughout the assessment study. For this purpose, the simultaneous determination of PAA and HP using the HPLC validated method has been applied and a kinetic model was developed. In addition, by using classified and statistical tools such as factorial ANOVA and Tukey's proof, the characteristic labelled groups in the sanitizer biocide samples were established for their distinction and differentiation. The results are shown and discussed.

\section{Material and Methods}

2.1. Apparatus. Analysis was performed with a Waters 2695 High Performance Liquid Chromatography (HPLC) with a Waters 2696 photodiode array detector. Compounds were separated on a SunFire C8 reversed phase column $(150 \mathrm{~mm}$ $\times 2.1 \mathrm{~mm} \times 3.5 \mu \mathrm{m})$. The injection volume was $10 \mu \mathrm{L}$, and the UV detection wavelength was $229 \mathrm{~nm}$. The following gradient of acetonitrile (A) and water (B) was selected to achieve separation of methyl p-tolyl sulphide (MTS), methyl $p$-tolyl sulfoxide (MTSO), triphenylphosphine (TPP), and triphenylphosphine oxide (TPPO): initial mobile phase ratio was held at $40 \% \mathrm{~A}$ and $60 \% \mathrm{~B}$ for $10 \mathrm{~min}$ and then programmed at $100 \% \mathrm{~A}$ and $0 \% \mathrm{~B}$ in $0.1 \mathrm{~min}$ and held for $1.8 \mathrm{~min}$ and then $40 \% \mathrm{~A}$ and $60 \% \mathrm{~B}$ in $0.1 \mathrm{~min}$ and held for $3 \mathrm{~min}$ to final run time ( $15 \mathrm{~min})$. The flow rate of the mobile phase was $0.45 \mathrm{~mL} \mathrm{~min}^{-1}$.

2.2. Reagents and Solutions. Peroxyacetic acid (PAA) 39\% and hydrogen peroxide (HP) 6\% from Sigma-Aldrich Química S.A. (Madrid, Spain) were used as standards for quantitation. Peroxide solution of PAA $\left(23.85 \mathrm{mmol} \mathrm{L}^{-1}\right)$ and HP $\left(8.21 \mathrm{mmol} \mathrm{L}^{-1}\right)$ was prepared under gravimetric control. Standard solutions of these peroxide solutions in acetonitrile were used for calibration curves of PAA.

All chemicals for the derivatization reaction were purchased from Sigma-Aldrich Química S.A. (Madrid, Spain) in the highest quality available: methyl $p$-tolyl sulphide (MTS) 99\%; triphenylphosphine (TPP) 98\%; methyl p-tolyl sulfoxide (MTSO) 97\%, and triphenylphosphine oxide (TPPO) $98 \%$. Standard solutions of MTS $\left(20 \mathrm{mmol} \mathrm{L}^{-1}\right)$ and TPP $\left(10 \mathrm{mmol} \mathrm{L}^{-1}\right)$ in acetonitrile were prepared and gravimetrically controlled. Vacu-vial kit patented for CheMetrics was purchased from Instrumentación Científica Técnica, S.L., Barcelona, Spain. Ammonium metavanadate 97\% was obtained from Panreac (Spain). Methanol and acetonitrile of HPLC grade were obtained from Sigma-Aldrich Química, S.A. (Madrid, Spain).

2.3. Samples. Four sanitizer biocide samples were studied: A to D. All of them were supplied by Biocidas Biodegradables ZIX Company (Huesca, Spain) with the following properties: sample A (25\% HP, 5\% PAA, and 5\% surfactant-1), sample B (25\% HP, 5\% PAA, and 2\% surfactant-2), sample C (25\% HP, 5\% PAA, and 1\% surfactant-3), and sample D (25\% HP, $5 \%$ PAA, without surfactant) (for confidentiality reasons, the BZIX company cannot give information on the type of surfactant used, but in all three cases the formula was different).

For this study, $0.010 \mathrm{~g}$ of biocide samples was diluted in $20 \mathrm{~mL}$ vials with Milli-Q water. The biocide samples were analysed in triplicate during 60 days.

In the first derivatization step $100 \mu \mathrm{L}$ of solution of MTS $\left(20 \mathrm{mmol} \mathrm{L}^{-1}\right)$ and $365 \mu \mathrm{L}$ of Milli-Q water were added to $35 \mu \mathrm{L}$ of diluted biocide sample or work solution of PAA for the calibration curve. After $10 \mathrm{~min}$ at room temperature, $400 \mu \mathrm{L}$ of acetonitrile and $100 \mu \mathrm{L}$ of solution of TTP $\left(10 \mathrm{mmol} \mathrm{L}^{-1}\right)$ were added to start the second derivatization step. The solutions were stored in the darkness for $30 \mathrm{~min}$ at room temperature and directly analysed by HPLC/UV.

\section{Results and Discussion}

3.1. Analytical Features of the Method. From the calibration curve the regression coefficient values and detection and quantification limits were calculated and are shown in Table 1. The daily measurement of blanks, standards, samples, and fortified samples with their corresponding duplicates for six days was used to calculate the recoveries, reproducibility, and repeatability of the analytical method for the determination of PAA and HP after the derivatization to MTSO and TPPO, respectively. The derivatization reaction is shown in (Figure 1).

Figure 2 shows the chromatograms obtained by HPLC/UV for calibration curve. The results show good linearity for both compounds under study and with the signal/noise ratio of the chromatograms corresponding to the blank and the first point on the calibration curve $\left(0.023 \mathrm{mmol} \mathrm{L}^{-1}\right.$ for PAA and $0.008 \mathrm{mmol} \mathrm{L}^{-1}$ for HP) the detection and quantifications limits were calculated.

Table 2 shows the recovery values, expressed as percentage of peroxyacetic acid and hydrogen peroxide standards analysed by HPLC/UV. As can be seen, the recovery values of both standards, PAA and HP, both at low concentration level $\left(2.22 \mathrm{mmol} \mathrm{L}^{-1}\right.$ and $0.76 \mathrm{mmol} \mathrm{L}^{-1}$, resp.) and at high concentration level $\left(23.85 \mathrm{mmol} \mathrm{L}^{-1}\right.$ and $8.21 \mathrm{mmol} \mathrm{L}^{-1}$, resp.) were from $90 \%$ to $103 \%$. 
<smiles>CSc1ccc(C)cc1</smiles>

FIgURE 1: Derivatization reactions of PAA and HP for their determination by HPLC.

TABLE 2: Recovery values expressed as percentage of the standards analysed with the HPLC/UV validated method.

\begin{tabular}{lcccc}
\hline Compound & Added $\left(\mathrm{mmol} \mathrm{L}^{-1}\right)$ & Recovered $\left(\mathrm{mmol} \mathrm{L}^{-1}\right)$ & Recovery $(\%)$ & Mean recovery $(\%)$ \\
\hline \multirow{2}{*}{ PAA } & 2.22 & 2.22 & 100 & 99 \\
\hline \multirow{2}{*}{ HP } & 23.85 & 23.71 & 90 & 99.5 \\
& 0.76 & 0.69 & 103 & 96.5 \\
\hline
\end{tabular}

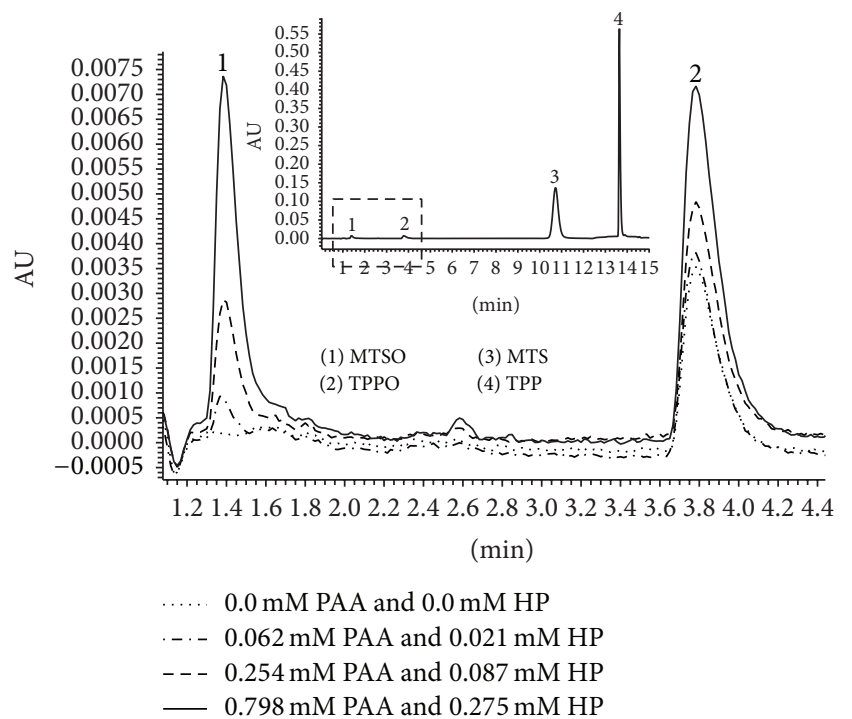

FIGURE 2: Overlay chromatograms of the calibration curve analysed by HPLC/UV.

3.2. Validation of the Analytical Method. According to the American Chemical Society (ACS) and its validation method guidelines, the precision level III or ruggedness is evaluated taking into account other validated methodologies and comparing their results about the interesting parameters, in this case with the determination of PAA and HP. The concentrations of both standards were also independently measured by UV/Vis spectroscopy, using the patented kit Vacu-vials ${ }^{(0}$ [23] in the case of PAA determination, and by $\mathrm{UV} / \mathrm{Vis}$ spectroscopy with metavanadate methodology [22] in the case of HP determination. The commercial samples were also analysed using these methods. The results obtained for the PAA and HP are shown in Figure 3.

For the four types of biocide samples, good agreements of the results using the spectrophotometric and chromatographic methods were achieved. In the case of peroxyacetic acid the results obtained were similar in the four samples of biocides. In the case of hydrogen peroxide the results obtained by UV/Vis spectroscopy were slightly higher than those obtained by simultaneous HPLC/UV analysis. This deviation can be explained by the simultaneous presence of two oxidants in the medium, HP and PAA, which is not detected by the spectroscopic methods. Reproducibility problems with spectroscopy UV/Vis methodologies have been described $[10,11]$. Therefore, the HPLC/UV method, where the surrogates were simultaneously determined, was proposed to analyze PAA and HP in real samples of disinfection control. The selectivity of HPLC-UV method is better, compared to the spectrophotometric methods, in which each oxidant should be independently analyzed.

3.3. Stability Study of Biocide Samples. During the study of stability carried out over two months it was observed that $\mathrm{pH}$ of the biocide samples remained stable, showing $\mathrm{pH}$ values between 0.6 and 0.8 , with variations of $0.1-0.2 \mathrm{pH}$ units. Therefore, these small variations of $\mathrm{pH}$ were considered negligible and did not influence the stability of the biocide samples. It is well known that changes in two $\mathrm{pH}$ units can accelerate the decomposition rate of peroxyacetic acid in the biocides [11, 21, 22].

The control of temperature is also a key parameter for the stability of peroxyacids and consequently very important to monitor the stability of the biocide samples, as temperature 


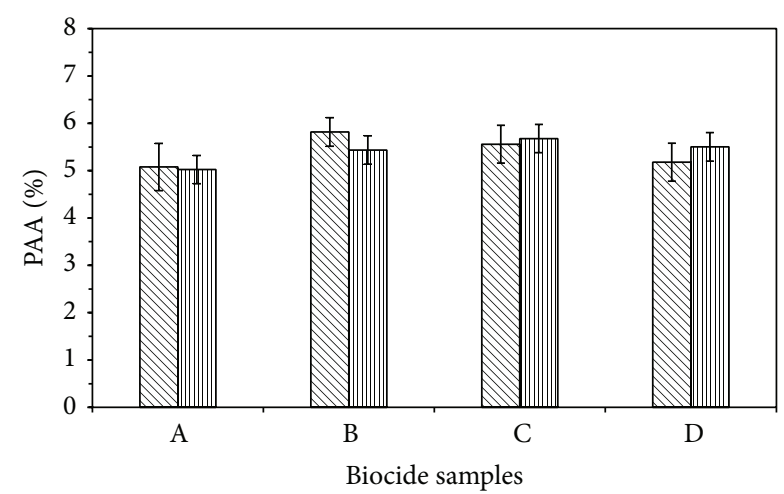

MPLC
UV-Vis

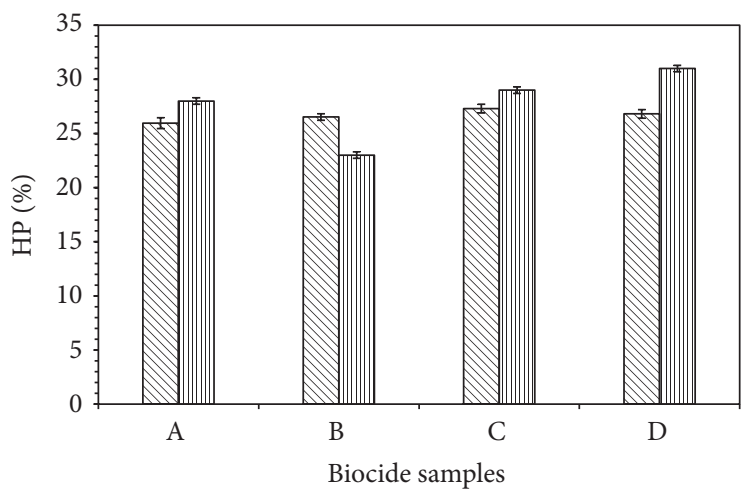

$\mathbb{N}$ HPLC

UV-Vis

(a)

(b)

FIgURE 3: Analysis of PAA (a) and HP (b) in biocide samples using a simultaneous HPLC/UV determination and UV/Vis spectroscopy methods.

affects the rate of decomposition of HP and PAA [9-11, 14, 2932 ], especially when temperatures are above $30^{\circ}$. In the first 35 days of study room temperature was held at $25^{\circ}$, but in the period from day 42 to day 63 , temperature reached up to $30^{\circ}$.

3.4. Peroxyacetic Acid Levels and Kinetic Study. Figure 4 shows the evolution graph of the peroxyacetic acid content during the study of four biocide samples. As can be seen, the results of the stability of peroxyacetic acid are influenced by two parameters: the temperature and the storage time $[14,29,30]$. Both parameters accelerate the decomposition reaction of peroxyacetic acid. According to the results shown in Figure 4 the following performance can be seen:

(1) Until day 42 of study, laboratory temperature remained constant and around $25^{\circ} \mathrm{C}$, so that the decomposition of peroxyacetic acid was spontaneous. The reduction of peroxyacetic acid content in this period was from $10 \%$ to $20 \%$.

(2) From day 42, the average temperature in the laboratory was about $30^{\circ} \mathrm{C}$, showing that the rate of peroxyacetic acid decomposition increased. The reduction of peroxyacetic acid content in this period was $27 \%$ for sample A and 39\% for sample B. Only sample C (with less amount of surfactant-3) and sample D (without surfactant) did not increase their decomposition rate of peroxyacetic acid in this period. These results agree with other studies from Wang et al. [30] carried out at constant temperature of $25^{\circ} \mathrm{C}$ in thermostatic chambers. Within the first 10 days the peroxyacetic acid reduction rate was $11 \%$ and after 30 days storage was $19 \%$, showing the influence of storage time as the only reason for the reduction of peroxyacetic acid. This statement coincides with the results obtained in this study, where there was acceleration in the rate of reduction of peroxyacetic acid for samples $A$ and $B$ in the period where the temperature exceeded $25^{\circ} \mathrm{C}$.

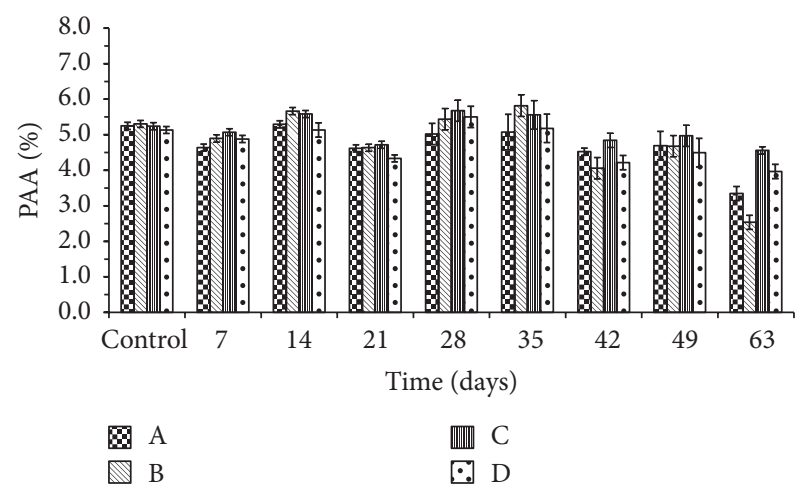

FIgURE 4: Evolution of peroxyacetic acid (PAA) in the biocide samples during stability study.

From the results obtained from the study a kinetic study was carried out in order to evaluate the main reason for the decomposition of peroxyacetic acid. Using the standard solutions the decomposition kinetic of peroxyacetic acid was obtained, showing a first-order reaction with a rate constant value $(k)$ of $1.70 \times 10^{-3} \mathrm{~h}^{-1}$ at $25^{\circ} \mathrm{C}$ with a standard solution of $2.22 \mathrm{mmol} \mathrm{L}^{-1}$ as initial peroxyacetic acid concentration. These data agree with the results obtained by Kunigk et al. [14]. Equation (1) was proposed to correlate concentration of peroxyacetic acid and time $(\theta)$ with a confidence level of $95 \%$. Equation (1) represents the curves shown in Figure 5. Consider

$$
\begin{aligned}
{[\mathrm{PAA}](0 \text { to } 35 \text { days }) } & =2.203 \cdot e^{-1.7 \cdot 10^{-3 \theta}} \text { at } 25^{\circ}, \\
{[\mathrm{PAA}](42 \text { to } 63 \text { days }) } & =4.858 \cdot e^{-2.25 \cdot 10^{-3 \theta}} \text { at } 30^{\circ} .
\end{aligned}
$$

Using the initial standard solution of $2.22 \mathrm{mmol} \mathrm{L}^{-1}$ Figure 5 was obtained. The percentage differences between the calculated values of peroxyacetic acid concentration with 


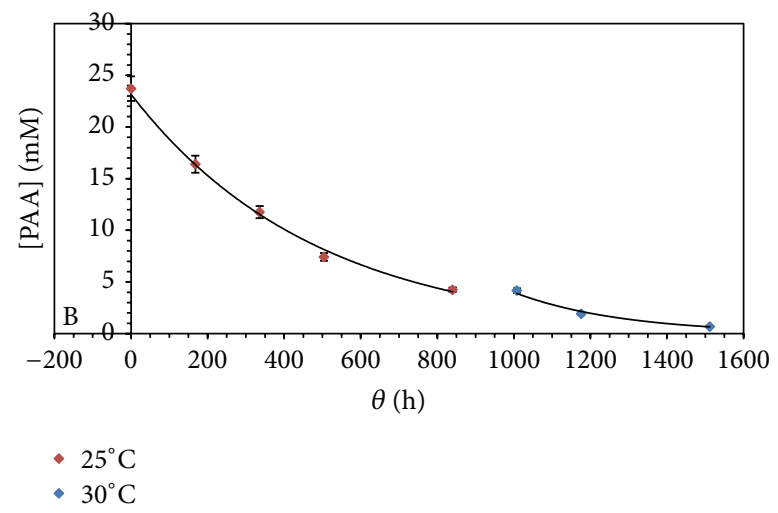

FIGURE 5: Variation of the initial concentration of $2.22 \mathrm{mmol} \mathrm{L}^{-1}$ peroxyacetic acid at $25^{\circ} \mathrm{C}$ and $30^{\circ} \mathrm{C}$ versus time $(\theta)$.

(1) and the corresponding experimental values of peroxyacetic acid concentration varied from 0.2 to $4.2 \%$ (average of $1.6 \%$ and standard deviation of $1.3 \%$ ).

With this assessment the influence of temperature and initial peroxyacetic acid concentration under decomposition kinetic of peroxyacetic acid was obtained. As expected, when temperature increased the kinetic constant increased. In Figure 5 the kinetic constant $(k)$ increased from $1.70 \times 10^{-3} \mathrm{~h}^{-1}$ to $2.25 \times 10^{-3} \mathrm{~h}^{-1}$ for standard of PAA $\left(2.22 \mathrm{mmol} \mathrm{L}^{-1}\right)$. According to Zhao et al. [31, 32], in this range of temperature the decomposition of PAA must be attributed to the hydrolysis process of PAA, but the temperature affects the two reactions (reversible reaction 1) in a similar degree. In addition, the hydrolysis of PAA in acidic medium is of first order with respect to PAA concentration, water concentration, and $\mathrm{H}^{+}$concentration [18]. Table 3 shows the influence of temperature $(T)$ on the specific decomposition rate constants $(k)$.

There was a good agreement between our data, the proposed model, and the experimental results from Kunigk et al. [14]. The percentage differences between the $k$ value, calculated with the Brazilian model and the Experimental Spain, corresponding to the experimental values of $k$ for $25^{\circ} \mathrm{C}$ and $30^{\circ} \mathrm{C}$, varied from $3.3 \%$ to $12.0 \%$ (average of $7.6 \%$ and standard deviation of $6.1 \%$ ). The equation of the Brazilian model, which correlates $k$ and $T$, may be used in our case to calculate the activation energy $\left(E_{a}\right)$ for the decomposition of PAA in aqueous solutions. For this purpose, the standard solutions used in this study showed that the Arrhenius law was obeyed, and the activation energy was $66.20 \mathrm{~kJ} \mathrm{~mol}^{-1}$. This value is comparable to the intrinsic activation energies of PAA synthesis and hydrolysis from the Arrhenius plot of $57.80 \mathrm{~kJ} \mathrm{~mol}^{-1}$ and $60.40 \mathrm{~kJ} \mathrm{~mol}^{-1}$, respectively, obtained by Zhao et al. [31]. With this value, it is possible to compare the efficiency of different stabilizers if the concentrations of the compounds present in the sanitizer formulation remain constant.

3.5. Peroxide Hydrogen Levels. Figure 6 shows the graphical representation of the evolution of the hydrogen peroxide

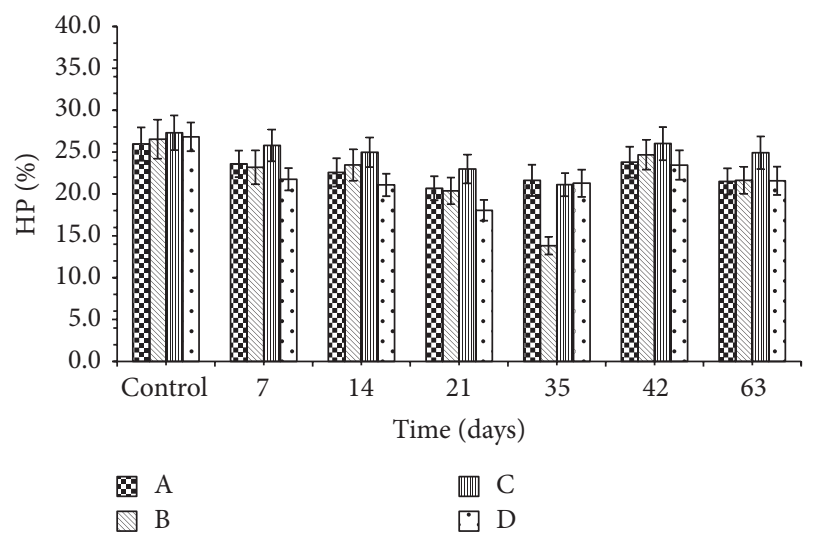

FIGURE 6: Evolution of hydrogen peroxide (HP) in the biocide samples during stability study.

content during the study of four biocide samples. When analyzing the stability of hydrogen peroxide, there was a decrease in the percentage of its own spontaneous decomposition.

As can be seen from the results shown in Figure 6 samples C (with less surfactant-3 composition) and D (without surfactants) are more stable, as the reduction of hydrogen peroxide content after 63 days is only $9 \%$ and $8 \%$, respectively. Furthermore, as in the case of the reduction in the content of peroxyacetic acid, samples A and B (with higher surfactant contents in their composition, resp.) showed higher rates of decomposition of hydrogen peroxide after 63 days, being 17\% and $15 \%$, respectively. It can be seen that the concentration of hydrogen peroxide is generally stable during the two months where its stability was evaluated, remaining around $20-25 \%$. These results agree with those obtained by Zhao et al. [32] which showed that the thermal decomposition of hydrogen peroxide in the liquid phase is not easily reached because the energy for breaking the $\mathrm{O}-\mathrm{O}$ bond is relatively high $\left(\sim 213 \mathrm{~kJ} \mathrm{~mol}^{-1}\right)$. Homolysis of hydrogen peroxide cannot happen unless it is heated above a critical temperature of $120^{\circ} \mathrm{C}$.

3.6. Factorial ANOVA for Assessment of Peroxyacetic Acid and Hydrogen Peroxide. Using a factorial ANOVA or univariate analysis of variance with the help of SPSS v15 software it was possible to elucidate some differences among the four sanitizer samples, grouping them in various subgroups. The first goal was to establish that all sanitizer biocide samples were statistically different, followed by the presence of interactions between the two factors evaluated: kind of sample and time. Then, with Tukey's HDS proof (Honestly Significant Difference), the existence of other types of linkage between them was demonstrated as it is shown below. The three selected factors, sample, time, and its mutual interaction included in the model, explain more than $98 \%$ and $83 \%$ of variance of dependent variables (for peroxyacetic acid and hydrogen peroxide concentration, resp.). It can be concluded from Tables 4(a) and 4(b) that the critical levels of significance show that the four samples have different mean concentrations of HP over the time of study. The same situation 
TABLE 3: The influence of temperature $(T)$ on the rate constant value $(k)$ for the kinetic decay PAA method developed.

\begin{tabular}{lcccc}
\hline$T(\mathrm{~K})$ & $\begin{array}{c}\text { Model Braz. } \\
k\left(\times 10^{3}\right)\end{array}$ & $\begin{array}{c}\text { Experimental Braz. } \\
k\left(\times 10^{3}\right)\end{array}$ & $\begin{array}{c}\text { Experimental Spain }^{\mathrm{b}} \\
k\left(\times 10^{3}\right)\end{array}$ \\
\hline 298 & 1.64 & 1.71 & 1.70 \\
303 & 2.55 & - & 2.25 & 3.3 \\
308 & 3.91 & 3.73 & - & - \\
313 & 5.91 & 5.38 & - & - \\
318 & 8.82 & 9.64 & - \\
${ }^{\mathrm{a}} k=e^{20.30} e^{-7959.85(1 / T)}$ & & &
\end{tabular}

${ }^{\mathrm{b}}$ Data were compared at the same initial PAA: $2.22-3.68 \mathrm{~mol} \mathrm{~L}^{-1}$.

TABLE 4: (a) Intersubject effects proof for peroxyacetic acid for the factorial ANOVA analysis. (b) Intersubject effects proof for hydrogen peroxide HP for the factorial ANOVA analysis.

(a)

\begin{tabular}{|c|c|c|c|c|c|}
\hline Source & $\begin{array}{c}\text { Sum of squares } \\
\text { Type III }\end{array}$ & $D_{f}$ & RMS & $F$ & Significance \\
\hline Corrected model & $28.357^{\mathrm{c}}$ & 27 & 1.050 & 56.491 & 0.000 \\
\hline Intersection & 1293.434 & 1 & 1293.434 & 69571.874 & 0.000 \\
\hline Sample & 1.731 & 3 & 0.577 & 31.032 & 0.000 \\
\hline Time & 21.495 & 6 & 3.582 & 192.696 & 0.000 \\
\hline Sample $*$ time & 5.131 & 18 & 0.285 & 15.333 & 0.000 \\
\hline Error & 0.521 & 28 & 0.019 & & \\
\hline Total & 1322.311 & 56 & & & \\
\hline Corrected total & 28.877 & 55 & & & \\
\hline
\end{tabular}

${ }^{\mathrm{c}} R^{2}=0.982$ (corrected $\left.R^{2}=0.965\right)$.

(b)

\begin{tabular}{|c|c|c|c|c|c|}
\hline Source & $\begin{array}{c}\text { Sum of squares } \\
\text { Type III } \\
\end{array}$ & $D_{f}$ & RMS & $F$ & Significance \\
\hline Corrected model & $573.777^{\mathrm{c}}$ & 27 & 21.251 & 5.334 & 0.000 \\
\hline Intersection & 29257.143 & 1 & 29257.143 & 7343.134 & 0.000 \\
\hline Sample & 62.140 & 3 & 20.713 & 5.199 & 0.006 \\
\hline Time & 278.940 & 6 & 46.490 & 11.668 & 0.000 \\
\hline Sample $*$ time & 232.698 & 18 & 12.928 & 3.245 & 0.003 \\
\hline Error & 111.560 & 28 & 3.984 & & \\
\hline Total & 29942.480 & 56 & & & \\
\hline Corrected total & 685.337 & 55 & & & \\
\hline
\end{tabular}

${ }^{c} R^{2}=0.837$ (corrected $\left.R^{2}=0.680\right)$.

occurred for PAA. In addition, the interaction sample time has a reliable effect under HP concentration, anticipating that the differences in the HP concentrations over the time of study are not the same in the four sanitizer samples (Table 4(b)). Again the same situation was found for PAA (Table 4(a)).

For PAA behaviour and in accordance with Tukey's proof it can be observed that only sample $C$ had differences with the rest of the samples $(p=0.000)$, while samples $A, B$, and D do not have differences between them (Table 5).

In addition, by using a post hoc procedure with Dunnet's proof (Table 5) and taking as control sample D (without surfactant), only sample C ( $1 \%$ surfactant- 3$)$ has shown significant differences $(p<0.000)$; this demonstrates how both the type and concentration of surfactant influence the behavior of samples biocides.

The behaviour of the hydrogen peroxyacetic acid is confirmed in Table 6, where the sanitizer biocide samples $\mathrm{C}$ and $\mathrm{D}$ had been grouped in one subgroup, each one separately, whereas sanitizer biocide samples A, B, and D have not been classified in another subgroup; sample $C$ offers the best conditions for stability.

Throughout the study of the significant interaction between sample and time (Figure 7) it is possible to confirm 
TABLE 5: Post hoc proof on multiple comparisons for peroxyacetic acid (PAA) taking into account the sample as independent factor.

\begin{tabular}{|c|c|c|c|c|c|c|}
\hline \multicolumn{7}{|c|}{ Multiple comparisons } \\
\hline \multicolumn{3}{|c|}{ Dependent variable: PAA } & \multicolumn{4}{|c|}{$95 \%$ confidence interval } \\
\hline (I) Sample & (J) Sample & Mean difference $(I-J)$ & Std. error & Sig. & Lower bound & Upper bound \\
\hline \multicolumn{7}{|c|}{ Tukey HSD } \\
\hline \multirow{3}{*}{ A } & $\mathrm{B}$ & -0.0566 & 0.05154 & 0.694 & -0.1973 & 0.0841 \\
\hline & $\mathrm{C}$ & $-0.4343^{*}$ & 0.05154 & 0.000 & -0.5750 & -0.2936 \\
\hline & $\mathrm{D}$ & -0.0364 & 0.05154 & 0.894 & -0.1771 & 0.1043 \\
\hline \multirow{3}{*}{ B } & $\mathrm{A}$ & 0.0566 & 0.05154 & 0.694 & -0.0841 & 0.1973 \\
\hline & $\mathrm{C}$ & $-0.3777^{*}$ & 0.05154 & 0.000 & -0.5184 & -0.2370 \\
\hline & $\mathrm{D}$ & 0.0202 & 0.05154 & 0.979 & -0.1205 & 0.1609 \\
\hline \multirow{3}{*}{$\mathrm{C}$} & $\mathrm{A}$ & $0.4343^{*}$ & 0.05154 & 0.000 & 0.2936 & 0.5750 \\
\hline & B & $0.3777^{*}$ & 0.05154 & 0.000 & 0.2370 & 0.5184 \\
\hline & $\mathrm{B}$ & 0.3979 & 0.05154 & 0.000 & 0.2572 & 0.5386 \\
\hline \multirow{3}{*}{$\mathrm{D}$} & A & 0.0364 & 0.05154 & 0.894 & -0.1043 & 0.1771 \\
\hline & B & -0.0202 & 0.05154 & 0.979 & -0.1609 & 0.1205 \\
\hline & $\mathrm{C}$ & $0.3979^{*}$ & 0.05154 & 0.000 & -0.5386 & -0.2572 \\
\hline \multicolumn{7}{|c|}{ Dunnett's test (bilateral) } \\
\hline A & $\mathrm{D}$ & 0.0364 & 0.05154 & 0.822 & 0.1643 & 0.0916 \\
\hline B & $\mathrm{D}$ & 0.0202 & 0.05154 & 0.961 & -0.1078 & 0.1482 \\
\hline $\mathrm{C}$ & $\mathrm{D}$ & $0.3979^{*}$ & 0.05154 & 0.000 & 0.2699 & 0.5259 \\
\hline
\end{tabular}

${ }^{*}$ The mean difference is significant at the 0.05 level.

TABLE 6: Homogeneous subsets for peroxyacetic acid (PAA) with Tukey's HDS proof.

\begin{tabular}{|c|c|c|c|c|}
\hline \multicolumn{5}{|c|}{ PAA } \\
\hline & \multirow{2}{*}{ Sample } & \multirow{2}{*}{$N$} & \multicolumn{2}{|c|}{ Subset } \\
\hline & & & 1 & 2 \\
\hline \multirow{5}{*}{ Tukey's HDS ${ }^{\mathrm{a}, \mathrm{b}}$} & A & 14 & 4.6741 & \\
\hline & $\mathrm{D}$ & 14 & 4.7105 & \\
\hline & B & 14 & 4.7307 & \\
\hline & $\mathrm{C}$ & 14 & & 5.1084 \\
\hline & Sig. & & 0.694 & 1.000 \\
\hline
\end{tabular}

${ }^{\mathrm{a}}$ Using the sample size of the harmonic mean $=14.000$.

${ }^{\mathrm{b}}$ Alpha $=0.05$.

that the sequential peroxyacetic acid concentration measured over the study was always lower than the earlier measurement. Sample $C$ has shown more stability than sanitizer biocide samples A, B, and D in terms of PAA concentrations. Thus, the influence of temperature on all samples under study is evident, especially in first two samples (A and B).

\section{Conclusions}

The simultaneous determination by HPLC of PAA and HP is possible and reliable to assess the decomposition of these compounds in biocide samples. The method was validated and only requires conventional HPLC equipment after the chemical reaction for derivatization.

The decomposition of peroxyacetic acid is a first-order reaction, and the corresponding rate constant is affected by temperature according to Arrhenius equation. The activation energy of the decomposition of peroxyacetic acid in aqueous standard solutions used in this work is $66.20 \mathrm{~kJ} \mathrm{~mol}^{-1}$.

The factorial ANOVA analysis allowed us to establish the interaction between time and the kind of sample (surfactant type and concentration) with respect to PAA and HP concentration. From the study carried out it can be concluded that biocide $\mathrm{C}$ with $1 \%$ of surfactant- 3 content in its composition offers the best conditions in terms of stability, and its difference with the other biocides may guarantee a better behaviour.

\section{Conflict of Interests}

The authors declare that there is no conflict of interests regarding the publication of this paper. 


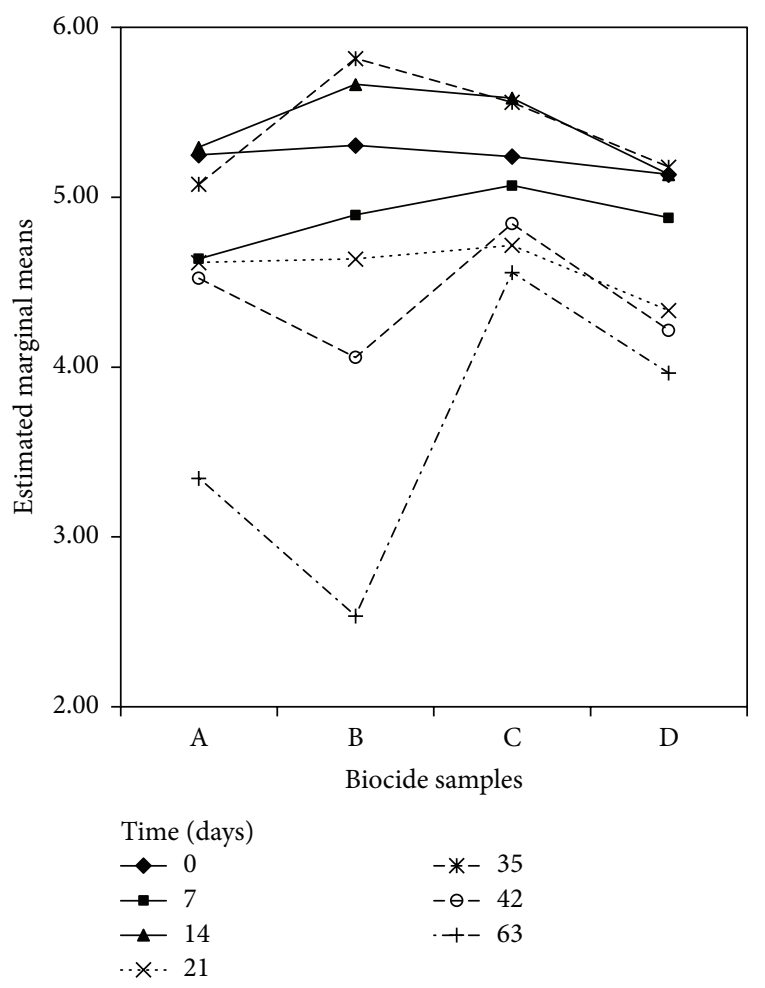

FIGURE 7: Profile plot of interaction between sample and time in the assessment of sanitizer biocide sample under factorial ANOVA analysis.

\section{Acknowledgments}

The authors are grateful for the support and invaluable collaboration received from Biocidas Biodegradables ZIX Company and Gobierno de Aragón and FEDER funds given to Grupo Consolidado de Investigación T-10.

\section{References}

[1] F. P. Greenspan and D. G. MacKellar, "Analysis of aliphatic per acids," Analytical Chemistry, vol. 20, no. 11, pp. 1061-1063, 1948.

[2] B. Phillips, F. C. Frostick Jr., and P. S. Starcher, "A new synthesis of peracetic acid," Journal of the American Chemical Society, vol. 79, no. 22, pp. 5982-5986, 1957.

[3] G. Kampf, P. M. Fliss, and H. Martiny, "Is peracetic acid suitable for the cleaning step of reprocessing flexible endoscopes?" World Journal of Gastrointestinal Endoscopy, vol. 6, no. 9, pp. 390-406, 2014.

[4] A. Bridier, R. Briandet, V. Thomas, and F. Dubois-Brissonnet, "Comparative biocidal activity of peracetic acid, benzalkonium chloride and ortho-phthalaldehyde on 77 bacterial strains," Journal of Hospital Infection, vol. 78, no. 3, pp. 208-213, 2011.

[5] M. Kitis, "Disinfection of wastewater with peracetic acid: a review," Environment International, vol. 30, no. 1, pp. 47-55, 2004.

[6] R. Gehr, D. Cochrane, and M. French, "Peracetic acid (PAA) as a disinfectant for municipal wastewaters: encouraging performance results from physicochemical as well as biological effluents," in Proceedings of the Water Environment Federation
Disinfection Conference, pp. 17-20, Petersburg, Fla, USA, February 2002.

[7] M. G. C. Baldry, M. S. French, and D. Slater, "The activity of peracetic acid on sewage indicator bacteria and viruses," Water Science \& Technology, vol. 24, no. 2, pp. 353-357, 1991.

[8] M. G. C. Baldry, “The bactericidal, fungicidal and sporicidal properties of hydrogen peroxide and peracetic acid," Journal of Applied Bacteriology, vol. 54, no. 3, pp. 417-423, 1983.

[9] D. L. Ball and J. O. Edwards, "The kinetics and mechanism of the decomposition of Caro's acid. I," Journal of the American Chemical Society, vol. 78, no. 6, pp. 1125-1129, 1956.

[10] R. C. Francis, X. Z. Zhang, P. M. Froass, and O. Tamer, "Alkali and metal-induced the composition of peroxymonosulfate," Tappi Journal, vol. 77, no. 6, pp. 133-140, 1994.

[11] Z. Yuan, Y. Ni, and A. R. P. Van Heiningen, "Kinetics of the peracetic acid decomposition: part II: $\mathrm{pH}$ effect and alkaline hydrolysis," The Canadian Journal of Chemical Engineering, vol. 75, no. 1, pp. 42-47, 1997.

[12] S. Monarca, S. D. Richardson, D. Feretti et al., "Mutagenicity and disinfection by-products in surface drinking water disinfected with peracetic acid," Environmental Toxicology and Chemistry, vol. 21, no. 2, pp. 309-318, 2002.

[13] A. Kramer, S. Reichwagen, P. Heldt, H. Widulle, and W. Nürnberg, "Oxidanzien," in Wallhäußers Praxis der Sterilisation, Desinfektion, Antiseptik und Konservierung, Assadian, Ed., Georg Thieme, Stuttgart, Germany, 2008.

[14] L. Kunigk, D. R. Gomes, F. Forte, K. P. Vidal, L. F. Gomes, and P. F. Sousa, "The influence of temperature on the decomposition kinetics of peracetic acid in solutions," Brazilian Journal of Chemical Engineering, vol. 18, no. 2, pp. 217-220, 2001.

[15] S. S. Block, Disinfection, Sterilization, and Preservation, Lea \& Febiger, Philadelphia, Pa, USA, 4th edition, 1991.

[16] Solvay Interox Product information for Proxitane EQ liquid 12 sanitizer, 2002, http://www.kellysolutions.com/.

[17] J. Gannon and S. Thornburgh, "The control of biofouling in aqueous systems by non-polymeric quaternary ammonium polyhalides," U.S. Patent PCT/US1987/002271, April 7, 1988.

[18] K. Rabone, "Improvements relating to antimicrobial cleaning compositions," Patent PCT/EP1996/004876, June 19, 1997.

[19] B. Herdt, R. Staub, K. Tauer, and K. Smith, "Wear resistant antimicrobial compositions and methods of use," Patent PCT/ IB2011/055555, June 21, 2011.

[20] F. P. Greenspan, R. J. Gall, and D. G. Mackellar, "Preparation and properties of perlauric acid," The Journal of Organic Chemistry, vol. 20, no. 2, pp. 215-217, 1955.

[21] U. Pinkernell, H.-J. Lüke, and U. Karst, "Selective photometric determination of peroxycarboxylic acids inthe presence of hydrogen peroxide," Analyst, vol. 122, no. 6, pp. 567-571, 1997.

[22] R. F. P. Nogueira, M. C. Oliveira, and W. C. Paterlini, "Simple and fast spectrophotometric determination of $\mathrm{H}_{2} \mathrm{O}_{2}$ in photoFenton reactions using metavanadate," Talanta, vol. 66, no. 1, pp. 86-91, 2005.

[23] CHEMetrics, P. A. V.-V. Kit, Editor: U.S. p. 2, 2011, https://www .chemetrics.com.

[24] J. Galbán, V. Sanz, and S. de Marcos, "Selective peracetic acid determination in the presence of hydrogen peroxide using a label free enzymatic method based on catalase," Analytical and Bioanalytical Chemistry, vol. 398, no. 5, pp. 2117-2124, 2010.

[25] F. Di Furia, M. Prato, U. Quintily, S. Salvagno, and G. Scorrano, "Gas-liquid chromatographic method for the determination of 
peracids in the presence of a large excess of hydrogen peroxide," The Analyst, vol. 109, no. 8, pp. 985-987, 1984.

[26] U. Pinkernell, S. Effkemann, and U. Karst, "Simultaneous HPLC determination of peroxyacetic acid and hydrogen peroxide," Analytical Chemistry, vol. 69, no. 17, pp. 3623-3627, 1997.

[27] I. A. Pettas and M. I. Karayannis, "Simultaneous spectrakinetic determination of peracetic acid and hydrogen peroxide in a brewery cleaning-in-place disinfection process," Analytica Chimica Acta, vol. 522, no. 2, pp. 275-280, 2004.

[28] D. Harms and U. Karst, "Rapid and selective determination of peroxyacetic acid in disinfectants using flow injection analysis," Analytica Chimica Acta, vol. 389, no. 1-3, pp. 233-238, 1999.

[29] Z. Yuan, Y. Ni, and A. R. P. Van Heiningen, "Kinetics of peracetic acid decomposition: part I: spontaneous decomposition at typical pulp bleaching conditions," The Canadian Journal of Chemical Engineering, vol. 75, no. 1, pp. 37-41, 1997.

[30] C. Wang, W. Zhang, Y. Lu, Q. Wei, and H. Z. Yang, "Experimental observation on term of validity of peracetic acid," Zhongguo Xiaoduxue Zazhi, vol. 22, pp. 307-308, 2005.

[31] X. B. Zhao, T. Zhang, Y. J. Zhou, and D. H. Liu, "Preparation of peracetic acid from hydrogen peroxide. Part I: kinetics for peracetic acid synthesis and hydrolysis," Journal of Molecular Catalysis A: Chemical, vol. 271, no. 1-2, pp. 246-252, 2007.

[32] X. B. Zhao, K. K. Cheng, J. B. Hao, and D. H. Liu, "Preparation of peracetic acid from hydrogen peroxide. Part II. Kinetics for spontaneous decomposition of peracetic acid in the liquid phase," Journal of Molecular Catalysis A: Chemical, vol. 284, no. 1-2, pp. 58-68, 2008. 

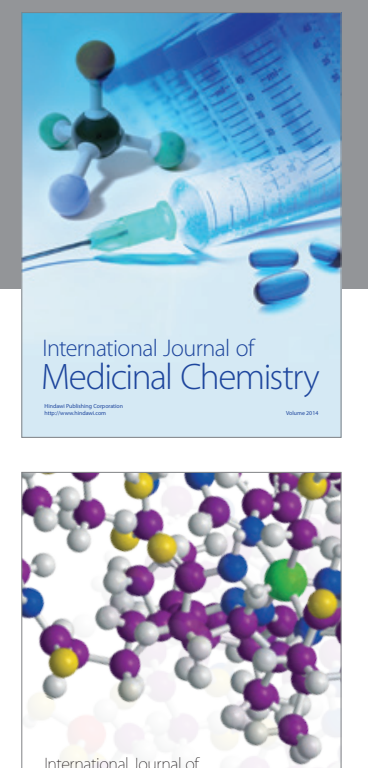

\section{Carbohydrate} Chemistry

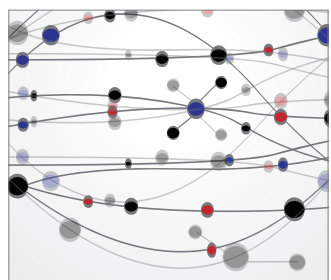

The Scientific World Journal
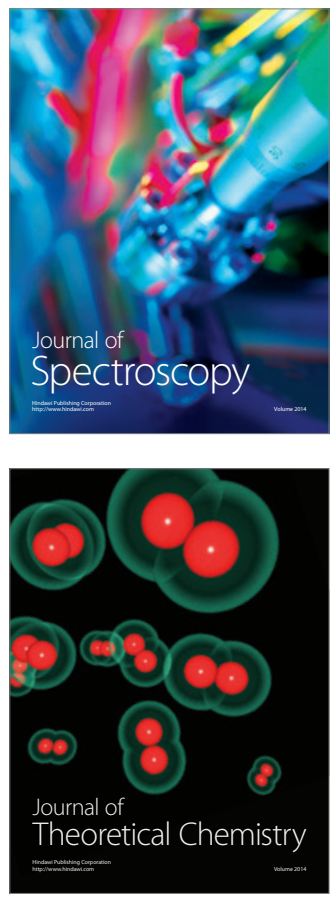
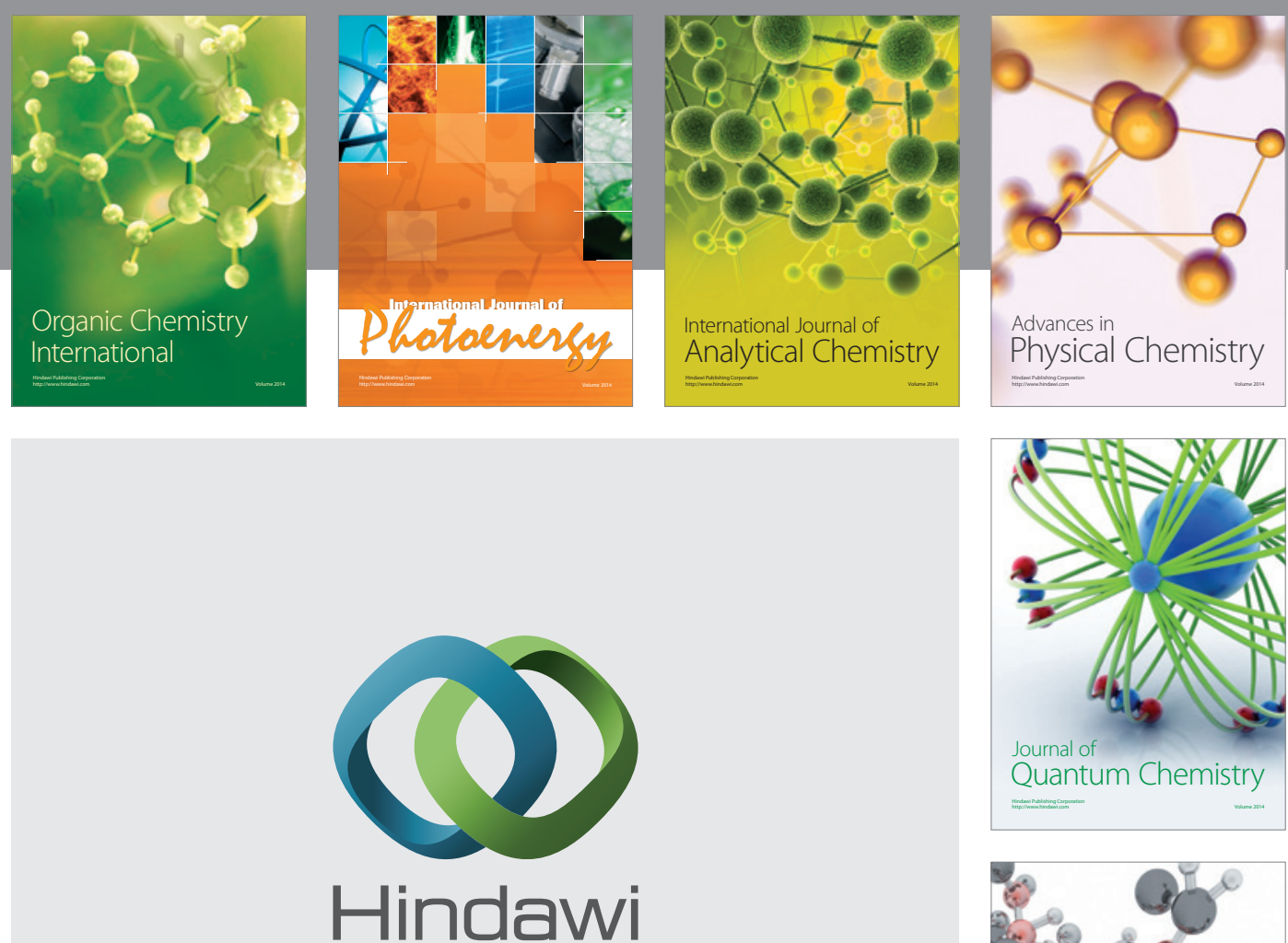

Submit your manuscripts at

http://www.hindawi.com

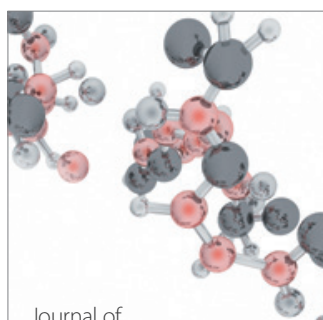

Analytical Methods

in Chemistry

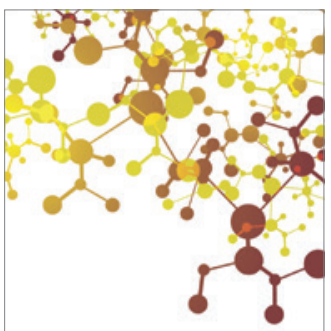

Journal of

Applied Chemistry

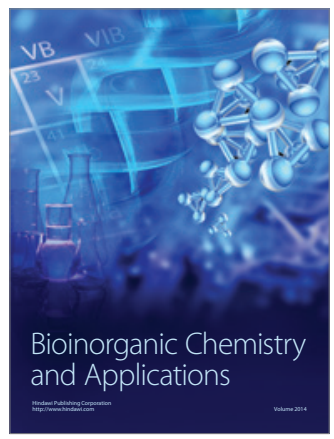

Inorganic Chemistry
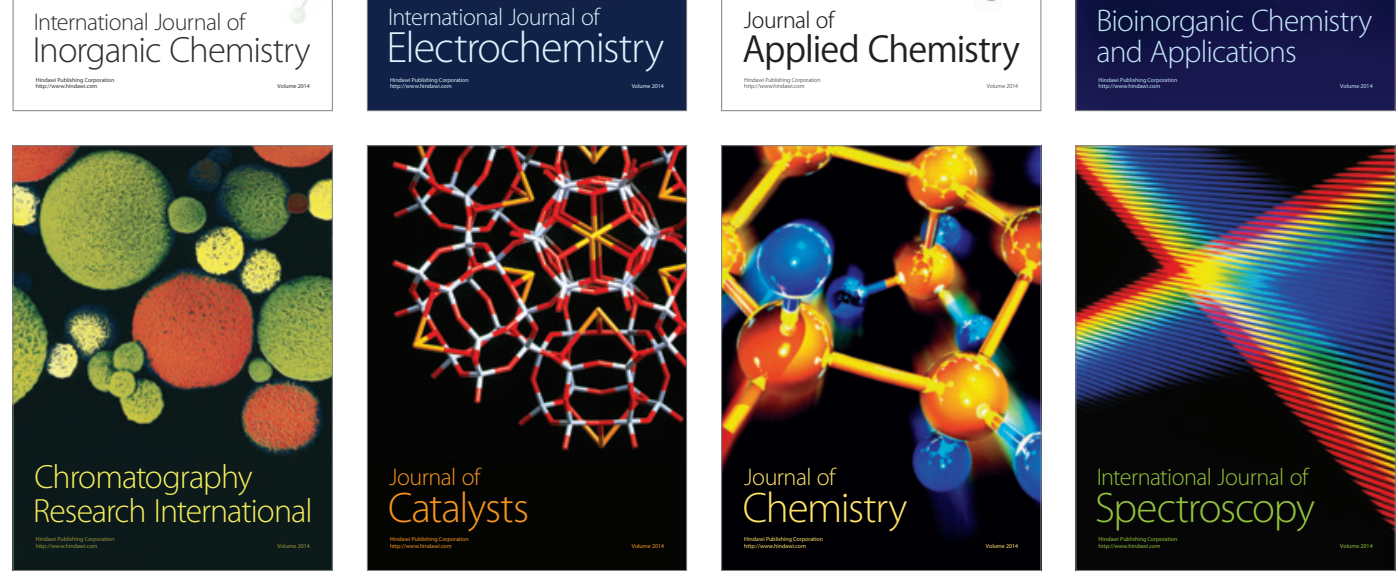